\title{
Factors Associated with Adherence to Sickle Cell Crisis Preventive-Practices among Youths of Sickle Cell Clubs in Abeokuta, Ogun State, Nigeria
}

\author{
Article by ${ }^{1}$ Nnodimele O. Atulomah \& ${ }^{2}$ Elizabeth O. Oyeneye \\ ${ }^{1,2}$ Department of Public Health, Babcock university, Ilishan, Nigeria \\ E-mail: ${ }^{1}$ atulomahn@babcock.edu.ng, ${ }^{2}$ foyeneye@yahoo.co.uk
}

\begin{abstract}
Adherence to sickle cell crisis preventive-practices is a major problem in at-risk population. Evidenced-based studies on factors associated with adherence to crisis prevention are few. This study sought to explore how the Information-Motivation-Behavioural Skill (IMB) model can provide understanding of underlying factors associated with adherence to crisis-preventive-practices behaviour among youths with sickle cell disease in Abeokuta, Nigeria.

This cross-sectional descriptive study employed a validated 43-item questionnaire to collect information from 84 participants who consented about crisis-risk prevention. Variables in the study were information, motivation, self-efficacy and adherence behaviour and measured on a 10-, 36-, 15- and 21- point scale respectively. Correlation and regression analysis was used to test for association, significance and prediction of best pathway to adherence with a cut-off at $p \leq 0.05$ level of significance.

The Mean Age of the participants was 20.07(0.69) \pm 6.28 with $40.5 \%$ males and $59.5 \%$ females. Majority were Yoruba and single with minimum of secondary school education. The sample mean scores reported for knowledge about crisis-prevention in sickle cell disease was $7.93 \pm 1.22$, motivation was $30.07 \pm 4.67$ and self-efficacy skills were $11.88 \pm 2.88$. The Adherence behaviour mean score was $11.23 \pm 3.30$ giving a behaviour prevalence rate of 53.5\%. Motivation was significantly associated with self-efficacy skills and adherence behaviour, while information was not significantly associated with either. Self-efficacy skills were significantly correlated with adherence behaviour. Path-analysis showed that the combined motivation and self-efficacy adherence behaviour $(r 2=0.34)$.

Findings showed that an informed and motivated sickle cell youth with good self-efficacy skills will adhere better to the crisis prevention-practices. The study recommends that counselling that provides information should be motivational to build self-efficacy that promotes crisis-prevention behaviour.
\end{abstract}

Keywords: Sickle cell crisis, preventive-practices, Information, Motivation, Adherence behaviour, Self-efficacy skill.

\section{Introduction}

Individuals with sickle cell disease are seriously challenged, particularly when they have to cope with repeated occurrence of associated crisis which in most cases is life threatening. Sickle cell disease crisis is a clinical emergency that require prompt attention. Invariably, this event is triggered by a number of factors that are preventable. Adherence to sickle cell disease crisis prevention-practices has been a challenge in the prevention of crisis and management of sickle cell disease. Generally, sickle cell disease is characterised by multiple morbidity and low quality of life as a result of the frequency of sickle cell crisis. Despite the increased life expectancy recorded in recent times due to medical advancement in the management of sickle cell disease, the morbidity profiles and health outcomes is still poor. However, many factors militate against adherence to preventive-practices and there is need to investigate these factors so that health care provider can develop a better workable strategy and intervention for prevention and management of sickle cell disease and crisis. 
Texila International Journal of Public Health

Volume 4, Issue 4, Dec 2016

Sickle cell disease is a genetic abnormality involving red blood cells and haemoglobin. It is estimated that 300,000 children are born with sickle cell disease every year globally (1). This directly translates to an estimated yearly global deaths of about 29,000 deaths. (2) It is found in many parts of the world, and most prevalent in sub-saharan Africa, India, Saudi Arabia and Mediterranean countries. In the Nigerian population, it is estimated that $25 \%$ of the population has the sickle cell trait AS-genotype and $2 \%$ are born annually with sickle cell disease SS-genotype with an estimated 150,000 children born every year in Nigeria with the disease(3).

Sickle cell disease is characterized by repeated and unpredictable painful episodes (crisis) capable of disabling its victims. Sickle Cell Crisis is a medical emergency. Signs and symptoms of sickle cell crisis can be mild or severe, can get worse over time and may change each time there is a crisis. Sickle cell crisis is characterized by pains in various parts of the body such as the back, stomach, chest, or bones, anaemia signs (headaches, and trouble breathing) pale skin colour change; Priapism (men's severe painful penile erection in the absence of sexual desire stimulation); Acute chest syndrome, chest pain and trouble breathing; Spleenicse questrian crisis characterised by feeling of weakness, shortness of breath with swollen abdomen and pain. Most crises last between five and seven days. Sickle cell crisis triggers could be unknown and varied for individual. Sickle cell crisis could be triggered by dehydration, microorganism infections of the host, inadequate supply of oxygen to the blood, low temperature, any form of stress, anger, frustration and depression. Treatment for sickle cell crisis includes coping with pain and other signs and symptoms, reducing pain during a crisis, prevention of a crisis from growing to become life-threatening and prevention of another crisis.

Sickle cell crisis can last between five and seven days and predisposing causes may be unknown. Many things could cause sickle cell crisis and it varies for individual. Sickle cell crisis may be triggered by dehydration, infections, hypoxia, cold temperature, surgery and emotional stress. Sickle cell crisis is the most complained and cause of hospital admission, however the crisis can be prevented most of the times by some preventive-practices which can reduce frequency of sickle cell crisis and improve quality of life.

Sickle cell disease can be managed by high fluid intake, healthy diet, folic acid supplementation, pain medication, vaccination and antibiotics for the prevention and treatment of infections, and other therapeutic measures (5). The recurrent pain and complications caused by the disease can affect the patient's quality of life and development. In order to prevent frequent sickle cell crisis, people living with sickle cell disease should rest during a sickle cell crisis, regular exercise, avoidance of sudden change of air pressure or lack of oxygen, avoidance of smoking and extremities of weather. The crisis prevention-practices is summarised into the following 4 components for the purpose of this study:

1. Routine medications and first aid,

2. Appropriate Diet \& rest,

3. Hazard \& infection control,

4. Keeping of routine medical check -up appointment

The Information, Motivation and Behavioural skill (IMB) model specifies that motivation acts as a catalyst to enhance health related behaviours and determines whether even wellinformed individuals will be inclined to undertake health promotion actions. Patients who is well-informed and well-motivated, but lacks critical behavioural skills, may be less likely to achieve or sustain high levels of adherence (6). The Fisher conceptual framework suggests that individuals, who are knowledgeable about HIV transmission and prevention, are motivated to prevent infection, and perceive themselves as capable of enacting preventive behaviours will act to reduce their HIV risk (7). The IMB model has been used with other youth populations. Youth with optimal knowledge about sickle cell disease and who receives maximum social support may likely be motivated to adhere to preventive-practices that may lead to improved quality of life (8). Despite the advancements in management of the disease, the global burden and morbidity is still on the rise, hence the need to look at factors 
associated with secondary preventive-practices and quality of life using an evidenced based theoretical model.

This study was undertaken to explore how IMB model theory and concept can provide understanding of factors such as information, motivational and self-efficacy is associated with adherence to preventive-practices behaviour in sickle cell crisis among youth with sickle cell disease. To my knowledge no study in Nigeria has explored the factors associated with sickle cell crisis preventive -practices among the youth using the IMB model construct. The sickle cell prevalence and burden in Nigeria is increasing (5). Preventive-practices can reduce frequency of crisis and improve quality of life, but there appears to be more to survival, coping and improved quality of life in sickle cell disease. Gaining a better understanding of the factors that influence adherence in any population of sickle cell may provide valuable information for theory and intervention. However, better understanding of adherence to preventive-practices in sickle cell disease is particularly critical for sickle cell patients in Abeokuta, Ogun state and Nigeria.

\section{Methods}

The study is a cross-sectional descriptive study carried out in Abeokuta, Ogun state located in the tropical rainforest of South-western Nigeria. A 43-itemquestionnaire which was based on IMB model conceptual domains of information, motivation, self-efficacy and behavioural skill was pilot tested with youths from sickle cell club of Ijebuland, Ogun state. Participants were drawn from a convenience sample of 84 youths aged 13years to 36years from the two sickle cell clubs in Abeokuta (Aglow sickle cell club and Hope Alive sickle cell club) with population of 800.Informed consent was sought from all who accepted to participate. The validated questionnaire was administered to consented 84 participants to evaluate crisis risk prevention information, motivation, self-efficacy and adherence behaviour with respect to sickle cell crisis prevention-practices measured on a 10-, 36-, 15- and 21- point scale respectively. The research was approved by ethical committee of Babcock University Ilisan, Ogun State, Nigeria.

The data collected were examined for completeness, coded manually and entered into a pass worded computer for analysis using the computer-assisted software Statistical Package for Social Sciences (SPSS) version 14 to conduct all statistical analysis. Descriptive statistics such as frequency distributions, means, standard error of mean (SEM) and standard deviation (SD) were used to evaluate levels of health information, motivation, self-efficacy and adherence behaviour. Regression analysis was conducted to validate the association between motivation, self-efficacy and adherence behaviour. Furthermore, path-analysis was conducted for the variables in the study to determine variables that most predict the adherence behaviour. The level of significance was set at $\mathrm{P}=0.05$ forallstatisticalprocedures.

\section{Results}

The demographic characteristics of the respondents are presented in table 1 . The Mean age of the respondents is 20.07 (SEM $=0.69$ ) \pm 6.28 , while minimum age is 13years and maximum age is 36years. The sample consisted of 84 youths with sickle cell disease of $40.5 \%$ male and $59.5 \%$ female. The majority are Yoruba (91.7\%) and single (89\%) with minimum of secondary school education (51.2\%). Up to $67.9 \%$ are students and $66.7 \%$ are Christians (table 1). The Study sample $\mathrm{N}=84$

The Mean Response Score of Sickle Cell Disease Risk-preventive Information, Motivation, Self - efficacy, knowledge and past Adherence Behaviour of the Respondents is presented in table 2

The mean information score $(7.93 \pm 1.22)$ is high. The mean score of computed motivation responses out of the 36-point scale measure of the respondents is mean \pm SD $(30.07 \pm 4.67)$. The sample can be said to be well motivated about the preventive-practices of sickle cell disease crisis. The mean score of computed self-efficacy skills responses out of the 15-point scale measure of the respondents is mean \pm SD $(11.88 \pm 2.88)$. The extent of self-efficacy 
Texila International Journal of Public Health

Volume 4, Issue 4, Dec 2016

estimated as the ratio between the correctly answered questions and the total asked questions $(11.88 / 15 \times 100 \%)=79.2 \%$. The respondents can be said to have good self-efficacy skills about preventive-practices of sickle cell disease crisis. The mean score of computed Adherence behaviour responses out of the 21-point scale measure of the respondents is mean $\pm \mathrm{SD}(11.23 \pm 3.30)$. The extent of adherence behaviour is estimated as the ratio between the correctly answered questions and the total asked questions $(11.23 / 21 \times 100 \%)=53.5 \%$. The respondents have about average adherence behaviour of preventive-practices of sickle cell disease crisis.

Table 1: Demographic Characteristics of the Respondents

\begin{tabular}{|c|c|c|}
\hline Variable & \multicolumn{2}{|l|}{ Responses } \\
\hline \multirow{4}{*}{$\begin{array}{l}\text { Gender } \\
\text { Male } \\
\text { Female } \\
\text { Fthnic } \text { oriain }\end{array}$} & Frequency & Per cent \% \\
\hline & 34 & 40.5 \\
\hline & 50 & 59.5 \\
\hline & \multicolumn{2}{|c|}{ Ethnic origin } \\
\hline Yoruba & 77 & 91.7 \\
\hline \multirow{3}{*}{$\begin{array}{l}\text { Igbo } \\
\text { Others } \\
\text { Marital status }\end{array}$} & 5 & 6.0 \\
\hline & 2 & 2.4 \\
\hline \multirow{2}{*}{\multicolumn{3}{|c|}{$\begin{array}{l}\text { Marital status } \\
\text { Single }\end{array}$}} \\
\hline & 75 & 89.3 \\
\hline \multirow{3}{*}{$\begin{array}{l}\text { Married } \\
\text { Widowed } \\
\text { Educational status }\end{array}$} & 8 & 9.5 \\
\hline & 1 & 1.2 \\
\hline & & \\
\hline \multirow{2}{*}{$\begin{array}{l}\text { primary } \\
\text { secondary }\end{array}$} & 9 & 10.7 \\
\hline & 43 & 51.2 \\
\hline \multirow{2}{*}{$\begin{array}{l}\text { tertiary } \\
\text { postgraduate }\end{array}$} & 25 & 29.8 \\
\hline \multirow{2}{*}{\multicolumn{3}{|c|}{ Occupation }} \\
\hline & & \\
\hline \multirow{2}{*}{$\begin{array}{l}\text { employed } \\
\text { Unemployed }\end{array}$} & 57 & 67.9 \\
\hline & 10 & 11.9 \\
\hline \multirow{2}{*}{$\begin{array}{l}\text { Self-employed } \\
\text { Religion }\end{array}$} & 7 & 8.3 \\
\hline & 10 & 11.9 \\
\hline \multirow{4}{*}{$\begin{array}{l}\text { Christianity } \\
\text { Islam } \\
\text { Traditionalist }\end{array}$} & & \\
\hline & 56 & 66.7 \\
\hline & 28 & 33.3 \\
\hline & 0 & 0.0 \\
\hline
\end{tabular}

Table 2: The Mean Response Score of Sickle Cell Disease Risk-preventive Information, Motivation, Self -efficacy, knowledge and past Adherence Behaviour of the Respondents

\begin{tabular}{|c|c|c|c|}
\hline \multirow[t]{2}{*}{ Variables: } & \multicolumn{3}{|l|}{ Responses } \\
\hline & $\begin{array}{l}\text { Maximum } \\
\text { Score }\end{array}$ & $\begin{array}{l}\text { Mean } \\
\text { Score }(\ddot{\mathbf{X}})\end{array}$ & \begin{tabular}{|l|} 
Standard \\
Deviation(SD)
\end{tabular} \\
\hline $\begin{array}{l}\text { Computation of Sickle cell disease Risk- } \\
\text { Prevention Information on a } 10 \text {-point scale }\end{array}$ & 10.00 & 7.93 & 1.22 \\
\hline $\begin{array}{l}\text { Computation of Sickle cell disease Crisis } \\
\text { Preventive-Practices Motivation on a } 36 \text { point } \\
\text { scale }\end{array}$ & 36.00 & 30.07 & 4.67 \\
\hline $\begin{array}{l}\text { Computation of Sickle cell disease Crisis } \\
\text { Preventive-Practices Self-Efficacy on a 15- }\end{array}$ & 15.00 & 11.88 & 2.88 \\
\hline
\end{tabular}




\begin{tabular}{|l|l|l|l|}
\hline point scale & & & \\
\hline $\begin{array}{l}\text { Computation of Sickle cell disease Crisis } \\
\text { Preventive-Practices past Adherence } \\
\text { Behaviour on a 21- point scale }\end{array}$ & 21.00 & 11.23 & 3.30 \\
\hline
\end{tabular}

The frequency distribution of correct responses on Sickle Cell Disease Risk-Prevention Information is as shown in table 3. The highest mean correct score (97.5\%) was recorded on information on healthy diet with plenty of water and rest as prevention of crisis, while the lowest score (44.0\%) was recorded on information about the cure of sickle cell disease. About $65.5 \%$ responded that adhering to the preventive-practices of sickle cell crisis all the time is necessary to prevent sickle cell crisis.

Table 3: Frequency Distribution of Respondents with Correct Responses on Sickle Cell Disease RiskPrevention Information.

\begin{tabular}{|l|l|l|}
\hline Variable: Sickle cell disease Risk-Prevention Information on & Responses \\
\cline { 2 - 3 } a 10-point scale & Frequency & Per cent \% \\
\hline $\begin{array}{l}\text { 1. Sickle cell disease is a generic abnormality involving red } \\
\text { blood cells. }\end{array}$ & 74 & 88.1 \\
\hline $\begin{array}{l}\text { 2. Prompt report of sickle cell crisis in the hospital within } \\
\text { 24hours can prevent complication and death. }\end{array}$ & 77 & 91.7 \\
\hline $\begin{array}{l}\text { 3. Sickle cell crisis can be prevented by some routine } \\
\text { preventive practices. }\end{array}$ & 78 & 92.9 \\
\hline $\begin{array}{l}\text { 4. Sickle cell crisis cannot be prevented by routine medications } \\
\text { (Folic acid, e.t.c) and first aid? }\end{array}$ & 53 & 63.1 \\
\hline $\begin{array}{l}\text { 5. Sickle cell crisis can be prevented by healthy diet with } \\
\text { plenty of water, and rest. }\end{array}$ & 82 & 97.5 \\
\hline $\begin{array}{l}\text { 6. Sickle cell disease is transmitted through kissing, coughing } \\
\text { and blood transfusion. }\end{array}$ & 72 & 85.7 \\
\hline 7. Sickle cell disease can be cured & 37 & 44.0 \\
\hline $\begin{array}{l}\text { 8. Adhering to the preventive-practices of sickle cell crisis all } \\
\text { the time is not necessary to prevent sickle cell crisis. }\end{array}$ & 55 & 65.5 \\
\hline $\begin{array}{l}\text { 9. Keeping regular medical check-up appointment can prevent } \\
\text { sickle cell crisis. }\end{array}$ & 76 & 90.5 \\
\hline $\begin{array}{l}\text { 10. Control of Hazard and infections can prevent sickle cell } \\
\text { crisis }\end{array}$ & 62 & 73.8 \\
\hline
\end{tabular}

Correlation is significant at the 0.05 level for Motivation and Adherence Behaviour. Correlation is significant at the 0.01 level for motivation and self-efficacy. However, correlation is not significant for other variable path to adherence and self-efficacy, such as Information and Motivation with adherence behaviour, Information and Self-efficacy, Information and Motivation with adherence behaviour, Self-Efficacy and Adherence Behaviour, Information and Adherence Behaviour (Table 4) 
Texila International Journal of Public Health

Volume 4, Issue 4, Dec 2016

Table 4: Summary of the Correlation Analysis of Variables measured in Sickle Cell Crisis PreventivePractices.

\begin{tabular}{|l|l|l|l|l|}
\hline S/N & Variables & $\begin{array}{l}\text { Pearson } \\
\text { correlation } \\
\text { coefficient (r) }\end{array}$ & $\begin{array}{l}\text { P- } \\
\text { value }\end{array}$ & Remarks \\
\hline $\mathbf{1}$ & $\begin{array}{l}\text { Information and } \\
\text { Motivation with } \\
\text { adherence behaviour }\end{array}$ & $0.066(\mathrm{r} 1)$ & 0.274 & $\begin{array}{l}\text { Correlation is not } \\
\text { significant }\end{array}$ \\
\hline $\mathbf{2}$ & $\begin{array}{l}\text { Information And Self } \\
\text { Efficacy }\end{array}$ & $-0.002(\mathrm{r} 2)$ & 0.491 & $\begin{array}{l}\text { Correlation is not } \\
\text { significant }\end{array}$ \\
\hline $\mathbf{3}$ & $\begin{array}{l}\text { Motivation and Self } \\
\text { Efficacy }\end{array}$ & $\mathbf{0 . 5 7 9}(\mathbf{r} 3)$ & $\mathbf{0 . 0 0 0 1}$ & $\begin{array}{l}\text { Correlation is } \\
\text { significant at the } \mathbf{0 . 0 1} \\
\text { level (1-tailed). }\end{array}$ \\
\hline $\mathbf{4}$ & $\begin{array}{l}\text { Self-Efficacy and } \\
\text { Adherence Behaviour }\end{array}$ & $0.003(\mathrm{r} 4)$ & 0.489 & $\begin{array}{l}\text { Correlation is not } \\
\text { significant }\end{array}$ \\
\hline 5 & $\begin{array}{l}\text { Information and } \\
\text { Adherence Behaviour }\end{array}$ & $0.003(\mathrm{r} 5)$ & 0.490 & $\begin{array}{l}\text { Correlation is not } \\
\text { significant }\end{array}$ \\
\hline 6 & $\begin{array}{l}\text { Motivation and } \\
\text { Adherence Behaviour }\end{array}$ & $\mathbf{0 . 1 9 8 ( r 6 )}$ & $\mathbf{0 . 0 3 5}$ & $\begin{array}{l}\text { Correlation is } \\
\text { significant at the 0.05 } \\
\text { level (1-tailed). }\end{array}$ \\
\hline
\end{tabular}

In order to determine the extent to which the IMB model constructs predicts adherence behaviour, significantly associated variables from table 4 (motivation, self-efficacy skills and adherence behaviour) were subjected to regression analysis. The respondent's score of information about the sickle cell crisis preventive-practices is not significantly correlated with adherence behaviour. ( $\mathrm{r} 5=0.003, \mathrm{p}=0.490$ ). The model indicated that self-efficacy skills $(\beta=$ $0.582, \mathrm{P}<0.001)$ and motivation $(\beta=0.199$., $\mathrm{P}<0.001)$ were both predictors of adherence to crisis preventive-practices. Information was not significantly correlated to adherence behaviour $(\beta=-0.10, \mathrm{P}>0.05)$ and behavioural skills $(\beta=-0.041, \mathrm{P}>0.05)$. Findings of this study indicated that self-efficacy skills were predicted by motivation of the respondents and not information. Regression Analysis R2 Value (0.337) indicates that the self-efficacy is predicted by about $33.7 \%$ ( $0.337 \times 100 \%)$ of motivation (Table 5).

Table 5: Regression Value for Dependent Variable: Self Efficacy and Independent variables (Motivation and Information) with respect to sickle cell crisis preventive-practices for Respondents

\begin{tabular}{|l|l|l|l|l|}
\hline & \multicolumn{4}{|c|}{ Dependent variable: Self-efficacy skills } \\
\hline Independent variables & R value & $\mathbf{R}^{2}$ value & B value & Beta value \\
\hline Motivation & 0.580 & 0.337 & 0.358 & 0.582 \\
\hline Information & & & -0.097 & -0.041 \\
\hline
\end{tabular}

Motivation predicted adherence behaviour $(\beta=0.199, \mathrm{P}<0.001)$ to sickle cell crisis preventive-practices. Regression Analysis $\mathrm{R}^{2}$ Value (0.039) indicates that the adherence behaviour is predicted by about $3.9 \%(0.039 \times 100 \%=3.9 \%)$ of motivation (Table 6.)

Table 6: Regression Analysis of Information and Motivation with Adherence Behaviour of sickle cell disease crisis preventive-practices for respondents

\begin{tabular}{|l|l|l|l|l|}
\hline & \multicolumn{4}{|l|}{ Dependent Variable: Adherence Behaviour } \\
\hline Independent variables & R value & $\mathbf{R}^{2}$ value & B value & Beta value \\
\hline Motivation & 0.198 & 0.039 & 0.203 & 0.199 \\
\hline Information & & & -0.41 & -0.10 \\
\hline
\end{tabular}




\section{Conceptual Model and Path Analysis}

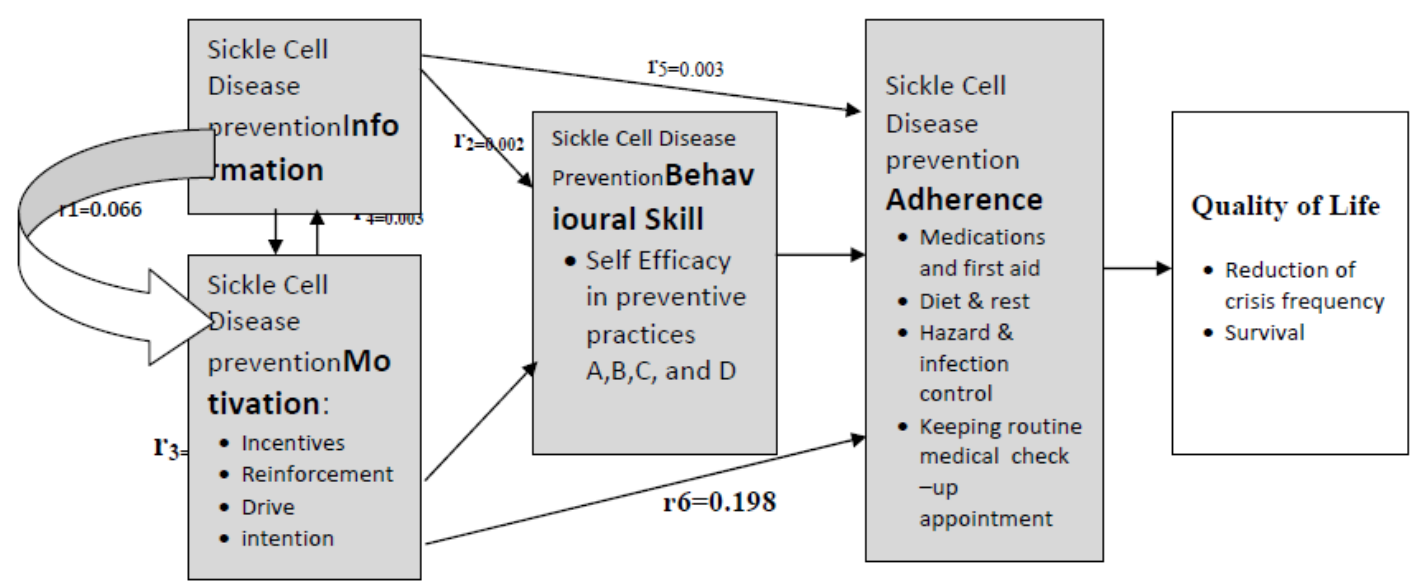

Figure 1: Path Analysis Regression for Factors Associated with Adherence to Sickle Cell Disease Crisis Preventive-Practices among Sickle Cell Disease Youth Based on the Information- MotivationBehavioral Skills (IMB) Model

Adherence behaviour is mostly predicted by motivation, which in turn was highly predicted by self-efficacy skills, the contribution of information to the adherence behaviour is very small from both path through self-efficacy and direct path to adherence from information. The resultant effect from information and motivation is also low; this suggests that motivation is the stronger predictor of self-efficacy which is responsible for the adherence behaviour. In practice a better motivated sickle cell youth will adhere better to the sickle cell disease crisis preventive-practices. This result is consistent with the report by Michele et al (2013), Zhu et al (2013) \& Jungling, et al, (2013) (9, 10,11). In essence study result has provided validity for the theoretical and conceptual framework that guided this study. (Figure 1)

\section{Discussion}

Despite the advances in the management of sickle cell disease, the global burden and morbidity is still unacceptably high. Sickle cell crisis is a preventable cause of hospital admission, morbidity and mortality. Adherence to crisis preventive-practices is a major problem in at risk population and evidenced based studies on factors associated with adherence to crisis prevention are few. The objective of this study therefore was to explore the dynamics involved in the use of the IMB model to provide predictors of adherence to crisis prevention-practices that could improve quality of life of at risk population. The study assessed the nature of associations between variables in the conceptual framework construct and ultimately determined the path-analysis that best predicted which path between information, self-efficacy skills and motivation provides better adherence to sickle cell crisis preventive-practices.

Information is an important resource that provides opportunity to make decisions about best options to choose to achieve set objectives. It is however important to note that basic knowledge and awareness about a medical condition that might include how the disease develops, its expected course and effective plans for its management are usually acquired through information dissemination. Motivation involves the dynamics of how various reinforces such as perceived social support from significant others may arouse desires in a person and drives the individual to behave in a particular way, for this study, adherence to crisis-prevention behaviour. Furthermore, how Behavioural skills construct accounts for the nature and level of confidence in the patient to perform the required adherence behaviour with the behavioural tools, social support and other self-regulation strategies or self-efficacy. The 
relationship between the information and motivation constructs is weak. However, in the IMB model, both information and motivation increase the chances of adherence behaviour.

The educational status of the study sample coupled with their experience of the disease and participation in the sickle cell club might have influenced their high level of information, yet, this does not necessarily translate to a correlation in crisis - prevention behaviour as the data from this study demonstrated. Since belief in the health behaviour can lead to behavioural change. The acquisition of knowledge about a disease is important in behaviour adaptation; especially if it is paired with believe that one's behaviour will have positive impact on health. (16). A person can only attempt to change his former behaviour if he believes in the new behaviour and then perceive that he can behave in the new prescribed behaviour. However, the result was not consistent with studies that reported that sickle cell patients mostly lack knowledge about their disease. The literature reported little, moderate and poor understanding or knowledge about sickle cell disease among sickle cell patients (17, 18 and 19). They recommended the need to educate the sickle cell patients about their illness. The finding of this study is inconsistent with this report, but it could also be assumed that the recommendation over the years was followed and the impact is our observation in the sickle cell patients in Abeokuta, Nigeria. The observed high score of information could also be the impact of the internet, school, sickle cell clubs and hospital education of the community, the students, the members of the club and the patients over the years. The awareness campaign is on and will yield better outcome if the effort remains consistent. This report is inconsistent with the report of Jaffer et al (3) where the sickle cell patients were moderately knowledgeable about the sickle cell crisis preventive measures (Mean of Knowledge score = $55 \%$ ). The respondent's knowledge (about the preventive measures) was found to be moderately and positively correlated $(r=0.57, r 2=0.32, p=0.000)$ with their attitudes toward crisis prevention. However, this study finding is consistent with the report of finding of Zhu et al(10) where the IMB model indicated that information was not significantly related to intention to smoke $(\beta=-0.001, \mathrm{P}>0.05)$ and behavioural skills $(\beta=0.002, \mathrm{P}>0.05)(10)$. Also the result is consistent with the report by Michele et al $(2013)$ \& Gao et al, $(2013)(9,11)$.

Adherence behaviour is mostly predicted by motivation, which in turn was highly predicted by self-efficacy skills, the contribution of information to the crisis - preventive behaviour is very small from both path through self-efficacy and direct path to adherence from information. The resultant effect from information and motivation is also low; this suggests that motivation is the stronger predictor of self-efficacy which is responsible for the adherence behaviour. This result is consistent with the report by Michele et al (2013), Zhu et al (2013) \& Jungling et al, (2013) (9, 10,11). In essence the study result has provided validity for the theoretical and conceptual framework (IMB model) that guided this study. (Figure 1). In practice a better motivated sickle cell youth will adhere better to the sickle cell disease crisis preventive-practices.

Motivation is positively correlated with self-efficacy for the respondents at 0.01 level $\left(\mathrm{r}=0.579, \mathrm{p}=0.0001, \mathrm{R}^{2}=0.337\right)$. Also motivation is significantly correlated with adherence behaviour at the 0.05 level $\left(r=0.198, p=0.035 \mathrm{R}^{2}=0.039\right)$. This study finding is consistent with the report of finding of Zhu et al where the model indicated that behavioural skills $(\beta=$ $0.670, \mathrm{P}<0.001)$ and motivation $(\beta=0.095, \mathrm{P}<0.001)$ were both predictors of intention to smoke. Furthermore, the model showed that motivation and behavioural skills were strongly related $(\beta=0.570, \mathrm{P}<0.001)$. Motivation was predicted by media exposure $(\beta=0.356, \mathrm{P}<$ $0.001)$, perceived smoking environmental $(\beta=0.409, \mathrm{P}<0.001)$, and normative expectations $(\beta=0.612, \mathrm{P}<0.001)(10)$.

The Information, Motivation and Behavioural skill model however asserts that to the extent that one is well-informed and well-motivated, he or she will acquire behavioural skills and apply these skills to the challenge of adherence to therapy. This finding may reflect youths' cumulative exposure to crisis prevention messages in the sickle cell clubs. The result is consistent with report of studies based on the extended IMB model for HIV studies where 
prevention information and motivation predicted behaviour and perceived self-efficacy skills. (6, 7 and 8$)$.

The extent of self-efficacy estimated as the ratio between the correctly answered questions and the total asked questions $(11.88 / 15 \times 100 \%=79.2 \%)$ is high. Motivation is positively correlated with self-efficacy for the respondents at 0.01 level $\left(r=0.579, p=0.0001, R^{2}=0.337\right.$ ). Since self-efficacy is acquired over time with practices, as the saying goes "practice makes perfect". Self-efficacy levels can enhance or impede the motivation to act. Individuals with high self-efficacy choose to perform more challenging tasks. They set themselves higher goals and stick to them (20). Actions are pre shaped in thought. Once an action has been taken, high self-efficacious persons invest more effort and persist longer than those with low self-efficacy. A sense of competence can be acquired by mastery experience, vicarious experience, verbal persuasion, or physiological feedback (21). Motivation is positively correlated with self-efficacy for the respondents at 0.01 level $\left(r=0.579, p=0.0001, R^{2}=0.337\right.$ ). The correlation between information and self-efficacy with respect to sickle cell disease preventive-practices is negative and not significant.

Despite the respondent's high level of information, motivation and self-efficacy, their crisis- prevention behaviour mean score is barely above average (percentage of the mean score to the total obtainable scores for adherence behaviour i.e. 11.22 / 21 x $100=53.42 \%$ ). This is suggestive of the fact that there are other factors and variance apart from information and motivation that are responsible for adherence behaviour. This result is consistent with the report by Fisher on "Adapting the Information-Motivation-Behavioural Skills Model: Predicting HIV-Related Sexual Risk among Sexual Minority Youth" where the results indicated that model variables accounted for $35 \%$ of the variance in primary sexual risk behaviours. The remaining factors are responsible for $66.3 \%$ of adherence behaviour (22). These other factors could be explored by another study.

The regression analysis indicates that motivation of the respondents predicted greater selfefficacy skills $\left(\mathrm{R}^{2}=0.337\right)$ than adherence behaviour $\left(\mathrm{R}^{2}=0.039\right)$ to sickle cell crisis prevention behaviour in the respondents. The IMB model demonstrates that information is a prerequisite for changing behaviour, but in itself is insufficient to achieve this change. Motivation and behavioural skills are critical determinants and are independent of behaviour change. This suggests that it may be particularly important to tailor sickle cell crisis risk prevention messages for youth around motivation in other to encourage them to develop selfefficacy skills needed to adhere to crisis preventive-practices. The linear regression model fit for this study is validated. Motivation of sickle cell youth is directly proportional to adherence behaviour with a positive intercept on the Adherence axis. Hence, an increase in adherence can be achieved with a proportionate increase in motivation achieved through self -efficacy skills.

Sickle cell crisis preventive - practices behaviour was mostly predicted by motivation, which in turn was highly predicted by self-efficacy skills. In essence the study result has provided validity for the theoretical and conceptual framework that guided this study for the sickle cell youth population.

Despite the social and medical information interventions, sickle cell crisis among youth is not abating. For this reason, research testing adapted models for this population, such as the present study, are urgently needed. These findings enhance our understanding of the sickle cell disease crisis risk prevention behaviours of sickle cell youth and provide a theoretical foundation for the development of preventive interventions tailored for this population. Effective prevention programs must therefore address the unique motivational factors that affect sickle cell crisis risk prevention. The IMB model used in this study offers insight into factors associated with adherence to sickle cell disease crisis preventive-practices for youth. Knowledge gained from this investigation is a first step toward developing innovative and culturally relevant interventions for an underserved youth population at high risk for sickle cell disease crisis in Abeokuta and by extension to all sickle cell youth globally. 
Texila International Journal of Public Health

Volume 4, Issue 4, Dec 2016

\section{Recommendations}

The sickle cell disease crisis consequences can be prevented if the sickle cell patients adhere to sickle cell disease crisis preventive-practices, take the responsibility of self-efficacy skills about crisis prevention and regular medical check-up, get involved in social activities designed for motivating sickle cell patients, be an active member of sickle cell club where support and motivation could be obtained to reduce the incidence of sickle cell disease crisis.

Similar research is recommended in other sickle cell clubs in other state in Nigeria to validate the Information, Motivation and Behavioural skill (IMB) model among the sickle cell population, in order to develop appropriate intervention to prevent sickle cell crisis. Stakeholders (Government, Nongovernmental organization, religious associations and institution, fathers, mothers, health workers, friends, schools, media and sickle cell clubs) should be involved and sponsor research to explore other factors that could predict adherence to crisis preventive-practices among sickle cell population and support same in any way they can in order to reduce mortality due to sickle cell disease crisis and complication.

\section{Limitation of the study}

These study findings should be considered in light of the following limitations. First, the convenience sample of 84 sickle cell youths recruited from the sickle clubs in Abeokuta limits the generalizability of findings to all young sickle cell youths, particularly those who are not involved with such clubs. Thus, study findings may be used to inform future sickle cell crisis preventive-practices interventions for sickle cell youth in other sickle cell clubs in other states in Nigeria and other African countries. Second, although the term predict is used in reference to path analysis, causality cannot be determined by non-experimental designs such as the one used in this study. Third, reliance on youth's self-reports may threaten data reliability and validity. However, strategies such as emphasizing confidentiality, and reminding respondents that their answers would be used to improve programs for sickle cell crisis prevention in youth were employed to facilitate accurate self-reports of respondents' behaviours. Finally, the IMB model tested in this study focuses on individual-level factors influencing sickle cell disease crisis prevention risk. It is likely that other factors are associated with adherence to crisis preventive-practices in the youth.

\section{The Contributions of this Study}

This study is significant because the findings would provide clear understanding regarding the dynamics involved with adherence to sickle cell crisis preventive-practices among this population. The finding also have policy implications: The Government, sickle cell patients and their parents, Non-Governmental Organisations (NGO's), and other stakeholders may also make use of the report of the study as need assessment to plan appropriate health promotion and education intervention. Furthermore, recommendations from the study would be useful in strengthening health Education counselling for these at - risk group. Finally, results of hypotheses regarding path analysis through which adherence is best achieved will provide validity of the theoretical framework that guided the study.

\section{Conclusions}

The IMB model indicated that behavioural skills (self-efficacy) $(\beta=0.582, \mathrm{P}<0.001)$ and motivation $(\beta=0.199$., $\mathrm{P}<0.001)$ were both predictors of adherence to crisis preventivepractices. Information was not significantly correlated to adherence behaviour ( $\beta=-0.10$, $\mathrm{P}>0.05)$ and behavioural skills $(\beta=-0.041, \mathrm{P}>0.05)$. Self-efficacy skills and motivation of the respondents predicted greater adherence to sickle cell crisis preventive-practices in the respondents. The study is consistent with IMB model. Sickle cell crisis risk prevention messages for youth should be tailored around motivation to develop self-efficacy skills to adhere to sickle cell crisis preventive-practices. Despite its limitations, this study added to knowledge and validated the IMB model on sickle cell disease crisis prevention information, 
preventive-practices motivation and self-efficacy as predictive factors for adherence behaviour to crisis preventive-practices among sickle cell population.

This research is a step toward developing a culturally specific IMB model of sickle cell disease crisis risk prevention, and findings have implications for policy, research and practice. Although the study results identify specific factors that may be important targets for sickle cell disease crisis preventive interventions with the youth, cross-sectional methods are limited in their assessment of developmental processes and trajectories. Longitudinal studies and mixed method approaches would provide opportunities to assess these important developmental processes and experiences more precisely and investigate the complex developmental trajectories of these youth more fully. Because subgroup analysis was not possible in this study, future research is needed to explore the predictive power of the IMB model with specific racial/ethnic groups of Nigerian's youth. Youth programs at sickle cell clubs should develop motivation related programs that include content on incentives, social support, reinforcements, drive and intention. Knowledge gained from this investigation is a first step toward developing innovative and culturally relevant interventions for an underserved youth population at high risk for sickle cell disease crisis in Abeokuta and by extension to all sickle cell youth globally.

\section{References}

[1] Al - Nasir F, Niazi G (1997). Sickle cell disease: patients' Awareness and management. Journal of Saudi Medicine. 18(1): 63 - 65

[2] Butler, Dennis, J, Beltran, Lou, R. (1993) Functions of an adult sickle cell group: Education, task orientation, and support. Health and Social Work, 18(1): 49 - 56

[3] Bandura Albert, (1977) Self efficacy: Toward a unifying theory of Behavioural change: Psychological Review vol 84, no 2,191-215

[4] Babwah F, Baksh S, Blake L, Cupid-Thuesday J, Hosein I, Sookhai A, Poon-King C, Hutchinson $\mathrm{G}$ (2006). The role of gender in compliance and attendance at an outpatient clinic for type 2 diabetes mellitus in Trinidad. Rev Panam Publication, 19(2); 79-84

[5] Fisher Colleen M. (2011): Adapting the Information-Motivation-Behavioral Skills Model: Predicting HIV-Related Sexual Risk among Sexual Minority Youth Health Education \& Behavior, published online 21 June 2011.

[6] Fisher WA, Fisher JD, Harman J (2003), The Information-Motivation-Behavioral skills model as a general model of health behavior change: Theoretical approaches to individual-level change. In: Suls J, Wallston K, editors. Social psychological foundations of health. Blackwell Publishers; London:127153.

[7] Fisher, Jeffrey D.; Fisher, William A.; Bryan, Angela D.; and Misovich, Stephen J., J (2002) "Information-Motivation-Behavioral Skills Model-Based HIV Risk Behaviour Change Intervention for Inner-City High School Youth" Health Psychology;2002;21 (2); 177-86.

[8] Fisher JD, Fisher WA. (1992) Changing AIDS-Risk Behavior. Psychological Bullettin, 111(3):455-74.

[9] Gil, KM, Abrams MR, Phillips G, Keefe FJ (1989). Sickle cell disease pain: Relation of coping strategies to adjustment. Journal of Consultant Clinical Psychology 57: 725 - 731

[10] Jaffer DE, Amrallah FK, Ali KM, Mohammed NA, Hasan RA and Humood ZM (2009) Adult Sickle cell disease patients' knowledge and attitude toward the preventive measures of sickle cell disease crisis. International Journal of Nursing and midwifery 1(2), 010-018. Journal of Intravenous Nursing, 21(1), 27-39

[11] Jungling Gao, Jingli Wang, Yaocheng Zhu and Jinming Yu, (2013): Validation of an Information-Motivation-Behavioural skills model of self-care among Chinese adults with type 2 diabetes. Biomed Central Public Health 13:100

[12] Lozano, (2010) Haematological parameters among sickle cell anaemia

[13] Locke E. A \& Latham, G.P (1990). A theory of goal setting and task performance Upper Saddle River, NJ: Prentice Hall. 
Texila International Journal of Public Health

Volume 4, Issue 4, Dec 2016

[14] Michele L.Ybarra, Josephine Korchmaros, Julius Kiwanuka, David R. Bangsberg and Sheana Bull (2013)Examining the applicability of the IMB model in predicting condom use among sexually active secondary school students in Mbarara, Uganda. AIDS Behaviour 17(3)1116-1128

[15] Mentzer, W. C., Heller, S., Pearle, P. R., Hackney, E., \&Vichinsky, E. (1994). Availability of related donors for bone marrow transplantation in sickle cell anemia. American Journal of Pediatric Hematology/Oncology, 16(1), 27-29.

[16] Ogamdi S (1994). African American Students' awareness of sickle cell disease. J.A m. Coll. Health 42 (5):234-236

[17] Okpala, Thomas, Westerdale, Jegede, Raj, Daley, Costello-Binger, Mullen, Rochester- Peart, Helps, Tulloch, Akpala, Dick, Bewley, Davies, and Abbs, 2002

[18] Simon, K., Lobo, M. L., \& Jackson, S. (1999). Current knowledge in the management of children and adolescents with sickle cell disease. Part 1: Physiology issues. Journal of Pediatric Nursing, 14(5), 281-295.

[19] World Health Organization, 2006

[20] World Health Organization, 2012

[21] Walters, M. C. (1999). Bone marrow transplantation for sickle cell disease: Where do we go from here? Journal of Pediatric Hematology/Oncology 2(6),

[22] Zhu, C., Cai Y., Ma, J., Li, N., Zhu, J., He, Y., Redmon, P., and Qiao, Y. (2013) Predictors of Intention to Smoke among Junior High School Students in Shanghai, China: An Empirical Test of the Information-Motivation-Behavioral Skills (IMB) Model. PLoS ONE, 8(11). 